\title{
Susceptibility of Chironomus plumosus larvae (Diptera: Chironomidae) to entomopathogenic nematodes (Rhabditida: Steinernematidae and Heterorhabditidae): Potential for control
}

\author{
Cassandra V. EDMUNDS, Craig S. WILDING and Robite RAE \\ Liverpool John Moores University, School of Natural Science and Psychology, Byrom St., Liverpool, L3 3AF, UK; \\ e-mails: S.Hughes-Crean@2011.ljmu.ac.uk, cvedmunds937@gmail.com, c.s.wilding@ljmu.ac.uk, r.g.rae@ljmu.ac.uk
}

Key words. Diptera, Chironomidae, Chironomus plumosus, Rhabditida, Steinernematidae, Steinernema, Heterorhabditidae, Heterorhabditis, biocontrol, chironomids, entomopathogenic nematodes, EPNs

\begin{abstract}
Chironomidae, or non-biting midges, are found worldwide in a wide variety of aquatic habitats. During periods of mass adult eclosion they can become a nuisance and health hazard. Current control methods target the aquatic larval stage and include the use of insect growth regulators or insecticides, which may be prohibited in certain environments or affect non-target organisms. The aim of this study was to investigate whether entomopathogenic nematodes (EPNs) of the families Steinernematidae and Heterorhabditidae, currently employed for control of terrestrial crop pests, could be used as a viable biocontrol for the aquatic larval stages of the Chrionomidae, offering an alternative to current chemical methods. We demonstrate that Steinernema feltiae (Filipjev, 1934), Steinernema carpocapsae (Weiser, 1955), Steinernema kraussei (Steiner, 1923) and Heterorhabditis bacteriophora (Poinar, 1975) are able to survive in water up to $96 \mathrm{~h}$ and are able to parasitize and kill Chironomus plumosus (Linnaeus, 1758) larvae, with mortality observed after just $24 \mathrm{~h}$ exposure and with $<20 \%$ survival after 4 days. We also show that following application to the water column, EPNs sink to the bottom of the lentic water body and can remain alive for more than $96 \mathrm{~h}$. Taken together, we believe that several EPN species could be developed as a valid form of biocontrol for Chironomidae.
\end{abstract}

\section{INTRODUCTION}

The Chironomidae is a large family of Diptera with a cosmopolitan range (Usher \& Edwards, 1984; Oliver \& Corbet, 1966 in Lin \& Quek, 2011) including two species found on the Antarctic continent (Oliver, 1971). Their ubiquitous nature may be in part due to the organism's tolerance of a wide range of environmental conditions including water temperature, and heavy metal pollution (Pinder, 1986). The Chironomidae is a holometabolous insect family, with the vast majority of the life cycle spent in an aquatic larval stage. With few exceptions, the short-lived adult stage of the organism does not feed, as the main purpose is to mate and oviposit (Oliver, 1971). To that end, Chironomidae exhibit adult mass emergence, which is thought to be a strategy evolved to increase the likelihood of finding a suitable mate and provide a sufficient quantity of individuals to allow sexual selection (Oliver, 1971; Lin \& Quek, 2011). The ubiquitous presence of Chironomidae in natural and man-made freshwater systems brings them into contact with human habitations where their mass emergence and aerial swarming can cause a nuisance (Failla et al., 2015).

The presence of all life stages of Chironomidae close to human activity causes a number of issues ranging from public health concerns to environmental and economic problems (Ali, 1980; Baur et al., 1982; Cranston et al., 1983; Sakai et al., 1993; Failla et al., 2015). Exposure to swarming adult stages can result in allergic reactions (Baur et al., 1982) leading to asthma attacks (Sakai et al., 1993), rhinitis (Cranston et al., 1981), discomfort and distress at adults flying into eyes, mouth or nose (Ali, 1980) and even asphyxia (Cranston et al., 1983). Other reported nuisances include causing traffic accidents through adults covering car windshields and lights, and dead Chironomidae causing road and airport runway surfaces to become slippery (Ali, 1980; Armitage et al., 1995; Failla et al., 2015), defacing of paintwork through meconium deposits from fresh emergents (Sakai et al., 1993, Ferrington, 2008) and general restriction of outdoor activity (Ali et al., 2008). The larvae can also be significant pests of agriculture, causing damage to rice seeds and plants if they enter the irrigated growing environment (Ali, 1980; Failla et al., 2015).

Current control methods take a number of forms including chemical control using insecticides and insect growth regulators (Tabaru et al., 1987; Stevens, 1992; Giddings et al., 2009; Failla et al., 2015). Physical control methods such as the use of highly-polarised light in traps and attraction of adults with sound (Hirabayashi \& Ogawa, 2000; Failla et al., 2015), rotational flooding and drying of breed- 
ing areas, increasing depth of water bodies and removal of substrate in concrete storm drains (Ali, 1980) have also been used. The effectiveness of these treatments is related to the species targeted and the places in which they are breeding, with not all species as susceptible as others (Failla et al., 2015). The use of these control treatments raises concerns as to the effects on non-target species (Failla et al., 2015) and increasing resistance to chemical control is a significant issue for future control programmes. Biological control methods, using natural enemies of Chironomidae larvae have included the use of Odonate nymphs (Arena \& Calver, 1996) or carp (Bay \& Anderson, 1965). It has also been previously documented that parasitic nematodes from the family Mermithidae are capable of parasitizing the aquatic larval stages of Chironomidae (Poinar, 1964; de Doucet \& Poinar, 1984; Johnson \& Kleve, 1996) but there is no research to date that explores the capability of entomopathogenic nematodes (EPNs) from the genera Steinernema and Heterorhabditis to parasitize Chironomidae.

EPNs are obligate parasites of insects (Poinar, 1979; Gaugler, 2002; Kaya et al., 2006). The only free-living stage; the infective juvenile (IJ) kills insects by penetrating through the cuticle, anal opening, spiracles or mouth and releasing their symbiotic bacteria: Xenorhabdus spp. for Steinernema spp. and Photorhabdus spp. for Heterorhabditis spp. (Forst et al., 1997; Shapiro-Ilan \& Gaugler, 2002). The host insect typically dies within $48 \mathrm{~h}$ and the EPNs then feed and reproduce, until the bacterial food supply within the decaying cadaver has been depleted, then the IJs move into the soil looking for new hosts (Gaugler \& Kaya, 1990; Gaugler, 2002).

Laboratory studies have shown that EPNs are able to penetrate and kill the larval stages of up to 200 species of arthropod (Laumond et al., 1979; Grewal et al., 1994; Georgis et al., 2006) including many vector and nuisance biting genera. Since the 1980 s, their natural pathogenicity towards arthropods has been utilised through their use as biological control agents for a range of insect pests. EPNs are currently used widely by growers of commercial or ornamental plant crops such as citrus, soft fruits and in greenhouse floriculture and forestry (Nguyen \& Duncan, 2002; Georgis et al., 2006; Cuthbertson \& Audsley, 2016). As EPNs are a 'natural enemy' of many pest species they can be considered to be a more environmentally friendly control method and as such are widely used in food crops where the use of traditional pesticides is banned or where growers wish to retain an 'organic' status (Kaya et al., 2006).

There have been some studies that have used EPNs to kill pestiferous aquatic insects. Poinar \& Kaul (1982) showed that Heterorhabditis bacteriophora could kill Culex pipiens larvae and Welch \& Bronskill (1962) found that Steinernema carpocapsae can kill and reproduce in Aedes aegypti larvae. Based on this knowledge this study sought to understand whether EPNs (Heterorhabditis and Steinernema) could kill and reproduce inside Chironomus plumosus and whether EPNs could therefore have the po- tential for development as a realistic biocontrol agent for chironomids.

\section{MATERIALS AND METHODS}

\section{Source of invertebrates}

Pelagial larvae of Chironomus plumosus were purchased from Andy's Aquatics, Wirral, U.K. and Chico's Pets, Liverpool, U.K. After purchase, larvae were immediately transported back to the laboratory where they were stored at $10^{\circ} \mathrm{C}$ in their original packaging. No food was provided for the C. plumosus larvae. Entomopathogenic nematodes (Steinernema feltiae, Steinernema kraussei, Steinernema carpocapsae and Heterorhabditis bacteriophora) were supplied by BASF Agricultural Specialities in a proprietary storage matrix and kept at $8^{\circ} \mathrm{C}$ until use. All EPNs were used within 28 days of receipt and all chironomid experimentation was initiated within 2 days of receipt of larvae.

\section{Survival of $C$. plumosus to different doses of EPNs and establishment of dose-response relationships}

EPN challenge was conducted in $200 \mathrm{ml}$ plastic-cups $(70 \mathrm{~mm}$ diameter top $\times 44 \mathrm{~mm}$ diameter base $\times 80 \mathrm{~mm}$ tall). Following guidelines from the World Health Organisation (2005) for larval testing twenty-five $C$. plumosus larvae were placed in separate disposable drinking cups containing $100 \mathrm{ml}$ of distilled water $(5$ $\mathrm{cm}$ depth). To the cups, $0,1000,2000,4000,8000$ or 16000 of each EPN species were added. These doses were based on testing multiples of the field application rate of 50 nematodes per $\mathrm{cm}^{2}$ (Campos-Herrera, 2015). The area of the cups $\left(38.46 \mathrm{~cm}^{2}\right)$ would warrant a dose of 1923 nematodes and we used a selection of doses that had previously been shown to kill a range of insects (Gaugler, 2002; Campos-Herrera, 2015). This process was repeated for each of the four tested EPN species. Each cup was covered with netting secured with an elastic band to avoid loss through emergence, and were incubated at $10^{\circ} \mathrm{C}$ to recreate the lower temperature water that $C$. plumosus would ordinarily inhabit (Hilsenhoff, 1966), yet be within the active range of the EPN species. Larval survival was recorded daily for 21 days. Larvae were adjudged to be dead if they were unresponsive when touched with a seeker. Each condition was tested 12 times. Any C. plumosus that died were examined for presence of nematodes.

\section{Potential pathogenicity of EPN transport medium}

EPNs are stored in a water dispersible gel carrier (proprietary formulation). To determine if this affected the survival of C. plumosus, EPN formulations were autoclaved at $121^{\circ} \mathrm{C}$ for $20 \mathrm{~min}$ to kill all EPNs and associated bacteria and allowed to cool to room temperature before being added to the plastic cups containing the Chironomidae larvae. It should be noted that the researchers were unable to separate the formulation from all the nematodes present therefore had to kill the nematodes via autoclaving and this may have changed the properties of the gel. The same amount of autoclaved gel formula as non-autoclaved formula with alive nematodes was added. This was repeated for each EPN species and repeated 3 times. The survival of $C$. plumosus was monitored daily for 21 days.

\section{Survival of EPNs in water column}

Soil-dwelling EPNs inhabit the water film between soil pores and the genera Steinernema and Heterorhabditis are not considered aquatic organisms. As such, it was important to discover if their survival would be affected when applied to water over time. Thirty plastic measuring cylinders (1 litre) were filled with 830 $\mathrm{ml}$ distilled water (a depth of $30 \mathrm{~cm}$ ). Each cylinder was marked at $5 \mathrm{~cm}$ intervals. Ten thousand $S$. feltiae were added to each cylinder. S. feltiae was used as it had the longest survival in prelimi- 


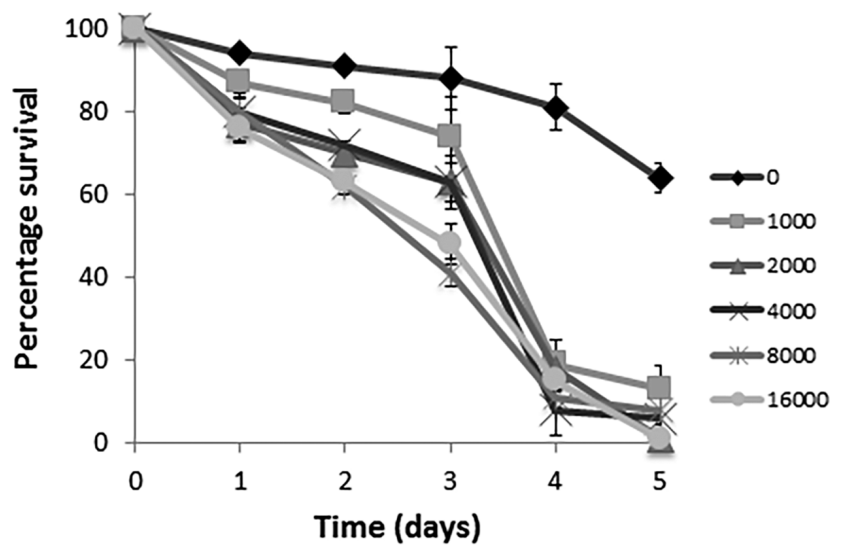

C

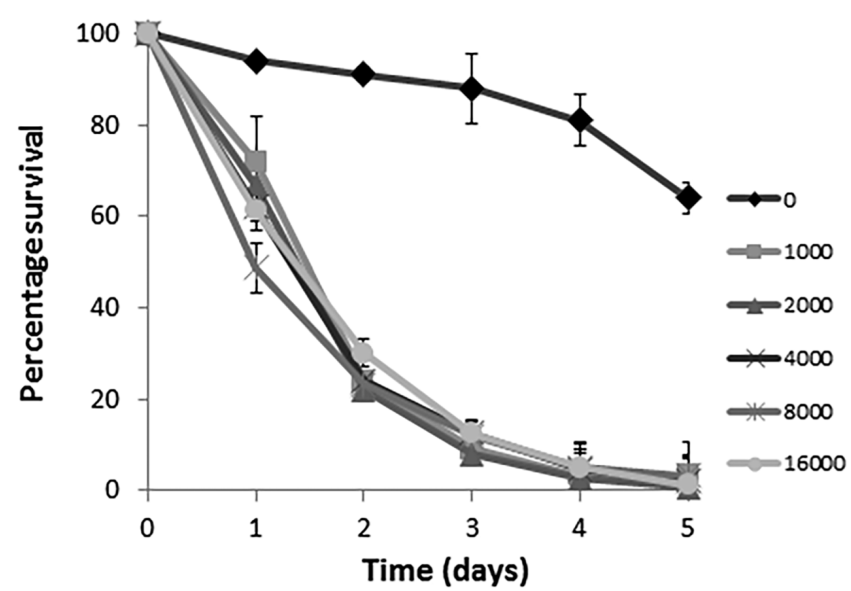

B

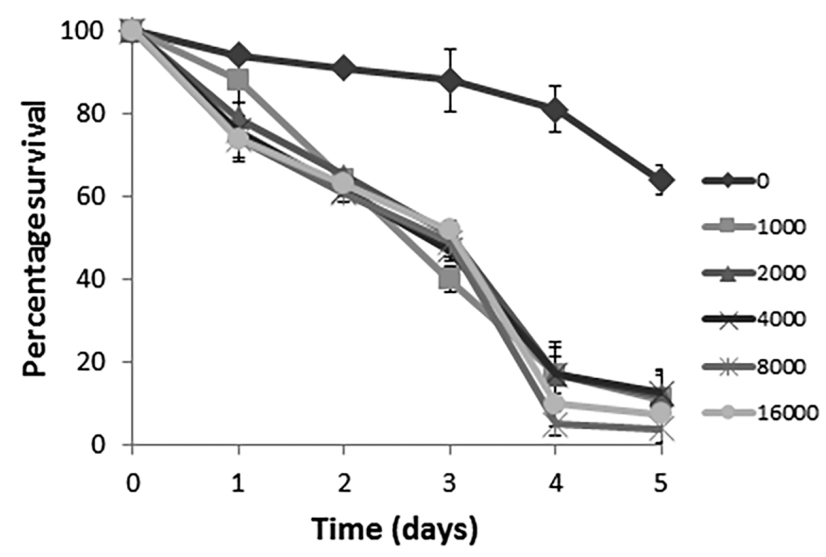

D

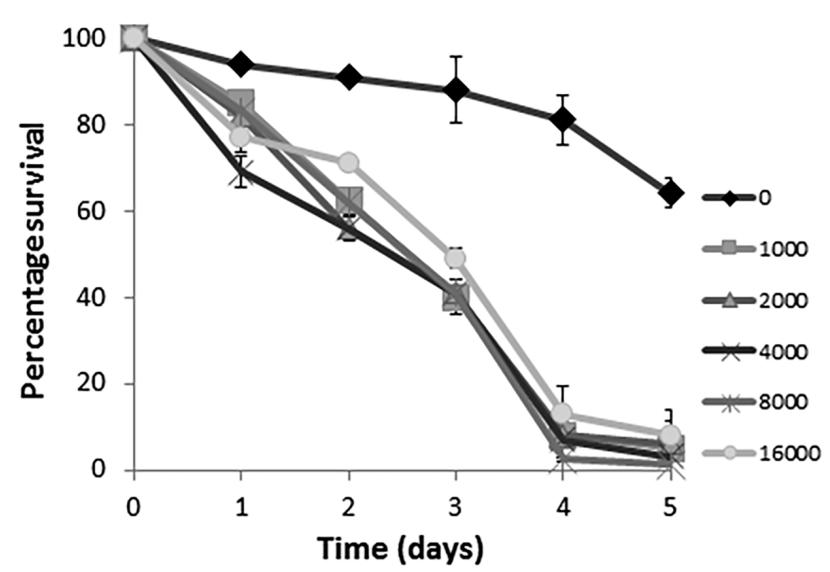

Fig. 1. Survival of C. plumosus exposed to $0,1000,2000,4000,8000$ and 16000 S. feltiae (A), H. bacteriophora (B), S. kraussei (C) and $S$. carpocapsae (D) for 5 days. Bars represent \pm one standard error.

nary, unpublished experiments. The cylinders were then covered with fine netting and secured with an elastic band. After $6 \mathrm{~h}, 150$ $\mathrm{ml}$ was removed at $5 \mathrm{~cm}$ intervals from the top of the cylinder using a rota-filler pipette, ensuring minimal disturbance to position of EPNs in the water column. The survival of nematodes was quantified from 3 cylinders. This process was repeated at 12, 24, 48 and $96 \mathrm{~h}$ after application of S. feltiae. Experiments were done in triplicate.

\section{Statistical analyses}

The survival of $C$. plumosus exposed to each EPN species and potential pathogenicity of the transport medium were analysed using Log-rank tests using OASIS software (Yang et al., 2011). As multiple comparisons were carried out the $\mathrm{P}$ value was adjusted to 0.01 using the Bonferroni correction.

\section{RESULTS}

\section{Survival of C. plumosus to difference doses of EPNs}

All four EPN species were effective in killing C. plumosus. At four days, survival was $<20 \%$ for treated larvae in comparison to $>80 \%$ for control larvae unexposed to EPNs. The survival of untreated C. plumosus was significantly different from those that were exposed to different doses of S. kraussei, S. feltiae, H. bacteriophora and S. car- pocapsae after 4 days exposure $(\mathrm{P}<0.01)$ (Figs $1 \mathrm{~A}-\mathrm{D})$. All nematodes (S. feltiae, H. bacteriophora, S. kraussei and $S$. carpocapsae) showed no significant dose-response with 1000-16000 being equally effective at killing chironomids (Figs 1A-D) $(\mathrm{P}>0.01)$ (for complete results of statistical analysis see Supplementary Table S1). H. bacteriophora, $S$. kraussei and $S$. carpocapsae showed clear larvicidal effects from day two onwards whilst significant effects were not seen until day four for $S$. feltiae $(\mathrm{P}<0.01)$. S. kraussei killed $C$. plumosus fastest with $<70 \%$ survival after just 2 days (Fig. 1) $(\mathrm{P}<0.001)$. When dead C. plumosus were examined for the presence of nematodes after 5 days exposure, infective juveniles were found that had penetrated inside from the initial experimental dose of nematodes (Fig. 2A) and that had developed into adults and reproduced via endotokia matricida of the first generation S. kraussei females (Fig. 2B).

\section{Potential pathogenicity of EPN transport medium}

EPNs are stored and transported in a transport matrix. It is possible that this substance has larvicidal effect either through toxicity or through interference with respiration. To rule out the possibility that this killed C. plumosus, experiments were conducted under conditions identical 

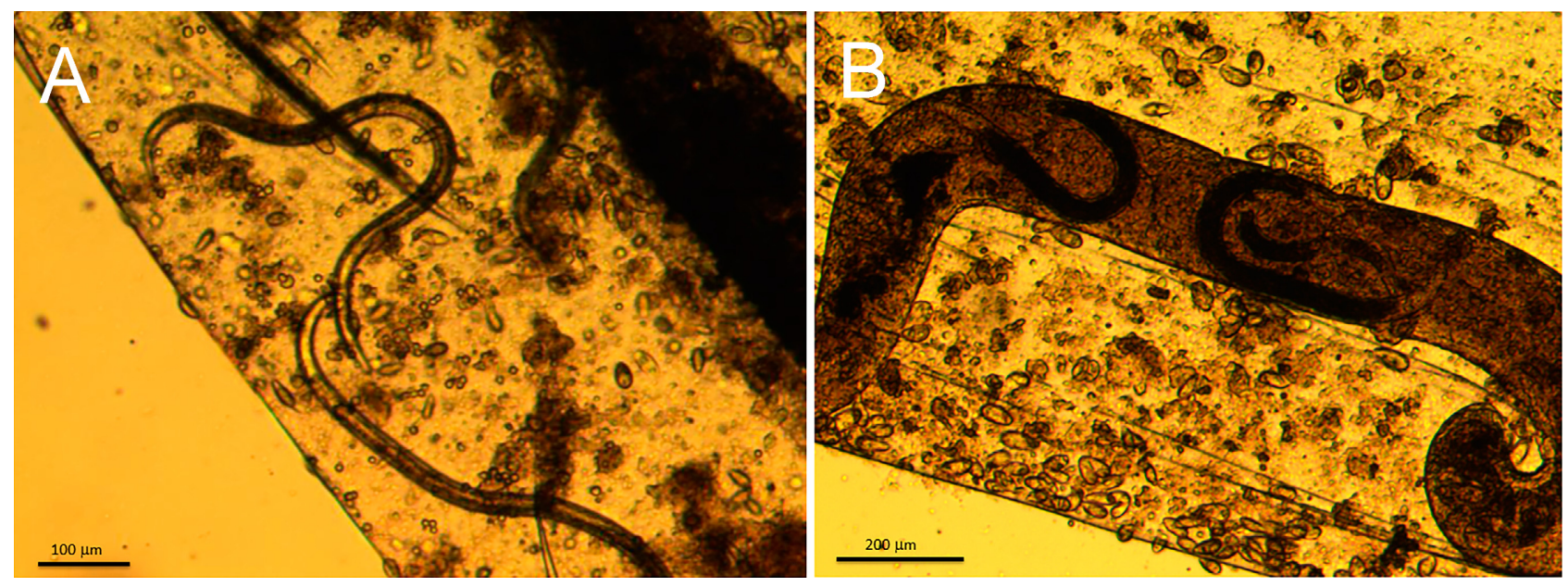

Fig. 2. Over 5 days $S$. kraussei were able to penetrate into $C$. plumosus (A) and reproduce via endotokia matricida in first generation mother (B). Scale bar represents $100 \mu \mathrm{m}$ in A and $200 \mu \mathrm{m}$ in B.

Table 1. Numbers of EPN (Steinernema feltiae) found at different water depths in a $30 \mathrm{~cm}$ column of water over time (up to $96 \mathrm{~h}$ ) following the addition of $\mathrm{N}=10,000$ nematodes.

\begin{tabular}{cccccc}
\hline \multirow{2}{*}{ Depth $(\mathrm{cm})$} & \multicolumn{5}{c}{ Mean number of Steinernema feltiae found \pm SE } \\
\cline { 2 - 6 } & $6 \mathrm{~h}$ & $12 \mathrm{~h}$ & $24 \mathrm{~h}$ & $48 \mathrm{~h}$ & $96 \mathrm{~h}$ \\
\hline $0-5$ & $47.11 \pm 14.64$ & $36.67 \pm 9.99$ & $14.67 \pm 3.64$ & $2.00 \pm 0.97$ & $5.11 \pm 0.73$ \\
$5-10$ & $59.56 \pm 18.61$ & $34.44 \pm 9.49$ & $36.67 \pm 12.38$ & $2.44 \pm 0.99$ & $6.33 \pm 1.12$ \\
$10-15$ & $87.78 \pm 22.33$ & $70.33 \pm 22.91$ & $83.11 \pm 36.92$ & $5.44 \pm 1.79$ & $6.33 \pm 2.06$ \\
$15-20$ & $90.67 \pm 19.5$ & $87.00 \pm 30.26$ & $122.56 \pm 58.59$ & $27.22 \pm 14.91$ & $8.11 \pm 2.04$ \\
$20-25$ & $119.56 \pm 25.65$ & $99.56 \pm 30.40$ & $122.56 \pm 58.59$ & $27.22 \pm 14.91$ & $9.44 \pm 2.04$ \\
$25-30$ & $9596.33 \pm 89.63$ & $9672.00 \pm 97.65$ & $9627.44 \pm 8.33$ & $9955.44 \pm 8.33$ & $9964.67 \pm 6.44$ \\
\hline
\end{tabular}

to the pathogenicity experiments except that nematodes and symbiotic bacteria were killed by autoclaving prior to commencement of the experiment. In contrast to the experiments using live EPNs there were no significant differences in the survival of $C$. plumosus exposed to different doses of gel transport medium form untreated control chironomids for $S$. kraussei $(\mathrm{P}=1.00) ;$ S. feltiae $(\mathrm{P}=1.00)$; H. bacteriophora $(\mathrm{P}=1.00)$ or $S$. carpocapsae $(\mathrm{P}=1.00)$ throughout the 7 days of exposure (Fig. 3).

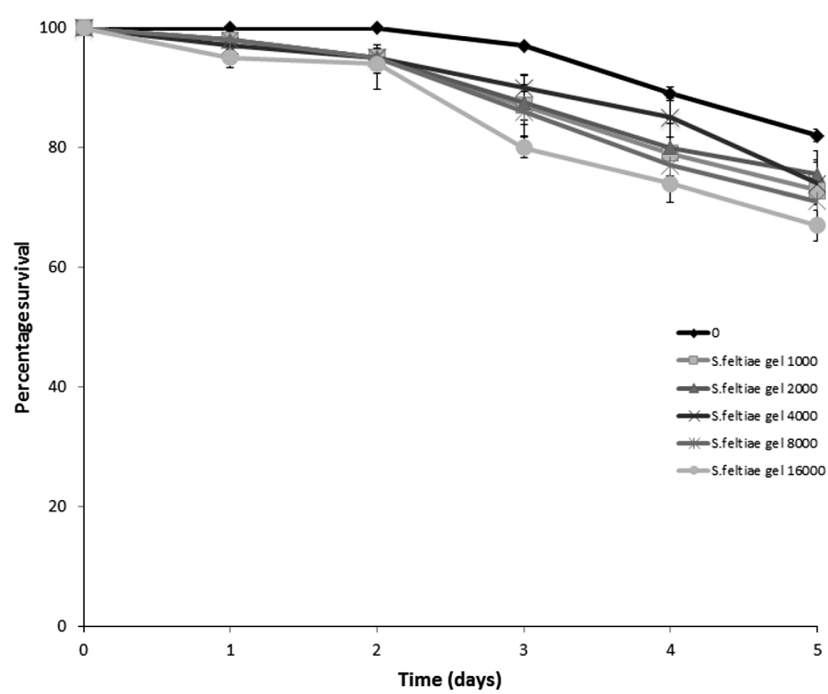

Fig. 3. The survival of $C$. plumosus exposed to $0,1000,2000$, 4000,8000 and 16000 autoclaved S. feltiae for 5 days. Bars represent \pm one standard error.

\section{Survival of EPNs in water column}

Chironomid larvae are bottom dwelling and therefore it is important that EPNs are indeed able to sink and survive at depth. Following just $6 \mathrm{~h}$ in a $30 \mathrm{~cm}$ water column the majority of nematodes were found at $25-30 \mathrm{~cm}$ depth of water and from 6-96 $\mathrm{h}>96 \%$ of nematodes were found alive and at the bottom of the water column (Table 1). Those found in the top of the water column after the first day were dead, suggesting that they had floated to the surface post-mortem.

\section{DISCUSSION}

This study found that aquatic larval stages of C. plumosus were parasitized and killed by four species of EPNs from two genera, with significant mortality observable after 2 days and the clearest mortality across all species visible after 4 days of exposure. S. kraussei exhibited the greatest pathogenic effect against C. plumosus larvae and required fewer nematodes to kill faster with only approximately $20 \%$ of the larvae alive after $24 \mathrm{~h}$ exposure. S. kraussei is known to be a cold tolerant EPN (Dolmans, 1983; Willmott et al., 2002; Laznik et al., 2009) with an effective thermal niche breadth of $6-10^{\circ} \mathrm{C}$ (Mráček et al., 1999; Long et al., 2000). The assays for this experiment took place at $10^{\circ} \mathrm{C}$, within the infection thermal niche for that species (Wilmott et al., 2002). Previous studies have shown that $S$. feltiae has an infective thermal niche breadth of $10-30^{\circ} \mathrm{C}, S$. carpocapsae $12-32^{\circ} \mathrm{C}$ and $H$. bacteriophora $12-32^{\circ} \mathrm{C}$ (Grewal et al., 1994) so they would not be inactive at the incubation temperature but may be more 
biologically active at warmer temperatures. The successful pathogenic effect of $S$. kraussei at a relatively low temperature indicates that it may be more suitable for practical application in colder or deeper water bodies and its quicker mortality rate against the $C$. plumosus larvae may enhance its effectiveness in water.

The nematodes utilised in this study were supplied in a proprietary gel-based matrix. The assay with the gel carrier medium was used to determine whether it had any mortality effect on the target organisms. We used exactly the same amount of autoclaved formulation as used in experiments using live nematodes with un-autoclaved media. All results for this were not significant in comparison to the control suggesting that there was no effect from the carrier medium. This might be expected since larval chironomids are apneustic (Armitage et al., 1995) and therefore the medium would not block the breathing tubes.

In order to effectively control benthic larvae EPNs must sink to the bottom of the water column and survive for the period required to exhibit mortality effects. The depth assay shows that over a $96 \mathrm{~h}$ period $S$. feltiae remained at the bottom of the water body. Those found in the top parts of the column after $12 \mathrm{~h}$ were dead, whereas those in the lower segment $(20-30 \mathrm{~cm})$ were alive suggesting that those higher in the water column had floated to the top following death. The results from this experiment indicate that EPNs sink to the bottom of the water body over 6-12 h as they cannot actively swim through the water column (Lewis et al., 1998) due to the lack of friction (Koppenhofer et al., 1995). When at the bottom of the cup they are presumably able to locate and penetrate through the mouth, anus, spiracles or even directly through the cuticle as in terrestrial insects (Gaugler, 2002). This behaviour was observed in a similar experiment by Poinar \& Kaul (1982) who described how $H$. bacteriophora penetrated directly through the anterior portion of the alimentary tract of $C$. pipiens larvae. The larval stages of the Chrionomidae life cycle are benthic (Prat \& Rieradevall, 1995) therefore a lack of swimming ability may not hamper the EPNs attempts to seek a Chironomidae host. The pathogenicity assays show that at the most effective EPN doses nematodes were able to penetrate and kill more than $90 \%$ of the Chironomidae within 4 days. After $96 \mathrm{~h}$ the majority of the EPNs were still alive, which demonstrates that although these obligate parasitic nematodes are not usually found in aquatic media, they could survive long enough to potentially be useful as a biocontrol agent for Chironomidae. If an application of EPNs could be timed precisely to coincide with the later instars of the larvae this would be more effective. Much research has been undertaken at sites where Chironomidae cause a particular nuisance and environmental parameters related to swarming behaviour measured (Lin \& Quek, 2011), so theoretically it may be possible to accurately time the introduction of EPNs to target later instars of the Chironomidae before emergence occurs.

The ability of the nematode to proliferate in insects in the soil habitat is key to their appeal as a biocontrol agent (Gaugler, 1988; Lacey \& Georgis, 2012). This study showed that a range of EPNs can kill chironomids and, crucially, not only the infective stages were observed within the chironomid carcasses but there was also evidence of reproduction. These results therefore show that EPNs can infect, kill and reproduce in C. plumosus, however, it is unknown whether the infective juvenile stage would survive emergence from the host in a deep aquatic environment and this requires further study if they are to be applied in the field, for example in reservoirs.

In conclusion, field trials of the use of EPNs to combat nuisance populations of Chironomidae are an essential step forward in the validity of their use as an effective biocontrol but the results from these laboratory studies are highly promising. The advantage of using EPNs as biocontrol are many, including that they are already produced on an industrial scale with a large body of research on best practice and effectiveness. Our data also raise the tantalising possibility that such EPNs could be developed for use in control of other insect species with aquatic larval stages such as mosquito and Simulium vectors.

ACKNOWLEDGEMENTS. I would like to thank P. Andrus for his laboratory assistance and BASF for the provision of EPNs.

FUNDING. This study was funded by Liverpool John Moores University.

CONFLICT OF INTEREST. The authors declare that they have no conflict of interest.

\section{REFERENCES}

Ali A. 1980: Nuisance chironomids and their control: a review. - Bull. Entomol. Soc. Am. 26: 3-16.

Ali A., Lobinske R.J., Leckel Jr. R.J., Carandang N. \& MazumDAR A. 2008: Population survey and control of Chironomidae (Diptera) in wetlands in northeast Florida, USA. - Fla Entomol. 91: 446-452.

Arena J. \& CALver M.C. 1996: Biological control potential of three species of nymphal Odonates against Polypedilum nubifer (Skuse), a nuisance midge (Diptera: Chironomidae). Austral. J. Entomol. 35: 369-371.

Armitage P.D., Cranston P.S. \& Pinder L.C.V. 1995: The Chironomidae: Biology and Ecology of Non-Biting Midges. Chapman and Hall, London, 447 pp.

Baur X., Dewair M., Fruhmann G., Aschauer H., Pfletschinger J. \& BRAunitzer G. 1982: Hypersensitivity to chironomids (non-biting midges): localization of the antigenic determinants within certain polypeptide sequences of hemoglobins (erythrocruorins) of Chironomus thummi thummi (Diptera) - J. Aller. Clin. Immunol. 69: 66-76.

BAY E.C. \& ANDERSON L.D. 1965: Chironomid control by carp and goldfish. - Mosq. News 25: 310-316.

Campos-Herrera R. 2015: Nematode Pathogenesis of Insects and Other Pests: Ecology and Applied Technologies for Sustainable Plant and Crop Protection. Springer, Zurich, 531 pp.

Cranston P.S., El Rab M.G. \& Kay A.B. 1981: Chironomid midges as a cause of allergy in the Sudan. - Trans. R. Soc. Trop. Med. Hyg. 75: 1-4.

Cranston P.S., Gad El Rab M.O., Tee R.D. \& Kay A.B. 1983: Immediate-type skin reactivity to extracts of the 'green nimitti' midge, (Cladotanytarsus lewisi), and other chironomids in asthmatic subjects in the Sudan and Egypt. - Ann. Trop. Med. Parasitol. 77: 527-533. 
Cuthbertson A.G. \& Audsley N. 2016: Further screening of entomopathogenic fungi and nematodes as control agents for Drosophila suzukii. — Insects 7(2): 24, 9 pp.

DE Doucet M.M. \& PoINAR JR G.O. 1984: Gastromermis kolleonis n. sp. (Nematoda: Mermithidae), a parasite of midges (Chironomus sp., Chironomidae) from Argentina. - J. Nematol. 16: 252-255.

Dolmans N.G.M. 1983: Biological control of the black vine weevil (Otiorrhynchus sulcatus) with a nematode (Heterorhabditis sp.). - Meded. Fac. Landbouww. Rijksuniv. Gent 48: 417-420.

Failla A.J., Vasquez A.A., Fujimoto M. \& Ram J.L. 2015: The ecological, economic and public health impacts of nuisance chironomids and their potential as aquatic invaders. - Aquat. Invas. 10(1): 1, $15 \mathrm{pp}$.

FERRINGTON L.C. 2008: Global diversity of non-biting midges (Chironomidae; Insecta, Diptera) in freshwater. - Hydrobiologia 595: 447-455.

Forst S., Dowds B., Boemare N. \& Stackebrandt E. 1997: Xenorhabdus spp. and Photorhabdus spp.: bugs that kill bugs. - Annu. Rev. Microbiol. 51: 47-72.

GAUGLER R. 1988: Ecological considerations in the biological control of soil-inhabiting insects with entomopathogenic nematodes. - Agric. Ecosyst. Environ. 24: 351-360.

GAUGLer R. (ED.) 2002: Entomopathogenic Nematology. CABI International, Oxon, $388 \mathrm{pp}$.

Gaugler R. \& KaYA H.K. 1990: Entomopathogenic Nematodes in Biological Control. CRC Press, Boca Raton, 365 pp.

Georgis R., Koppenhöfer A.M., Lacey L.A., Bélair G., DunCAN L.W., Grewal P.S., SAmish M., Tan L., Torr P. \& van Tol R.W.H.M. 2006: Successes and failures in the use of parasitic nematodes for pest control. - Biol. Contr. 38: 103-123.

Giddings M.M., Magara Y. \& Ohanian E. 2009: Temephos in Drinking-water: Use for Vector Control in Drinking-water Sources and Containers. WHO. URL: http://www.who.int/ water_sanitation_health/dwq/chemicals/temephos.pdf

Grewal P.S., Selvan S. \& Gaugler R. 1994: Thermal adaptation of entomopathogenic nematodes: niche breadth for infection, establishment, and reproduction. - J. Therm. Biol. 19: 245253.

Hilsenhoff W.L. 1966: The biology of Chironomus plumosus (Diptera: Chironomidae) in Lake Winnebago, Wisconsin. Ann. Entomol. Soc. Am. 58: 465-473.

Hirabayashi K. \& Ogawa K. 2000: Field study on capturing midges, Propsilocerus akamusi (Diptera: Chironomidae), by artificial wingbeat sounds in a hyper-eutrophic lake. - Med. Entomol. Zool. 51: 235-242.

Johnson A. \& KLeve M. 1996: Strelkovimermis acuticauda sp. and Strelkovimermis buccalis sp. (Nematoda: Mermithidae) from adult chironomids (Diptera: Chironomidae) from Lake Itasca, Minnesota. - J. Parasitol. 82: 478-483.

Kaya H.K., Aguillera M.M., Alumai A., Choo H.Y., De la Torre M., Fodor A., Ganguly S., Hazir S., Lakatos T., Pye A. \& WILSON M. 2006: Status of entomopathogenic nematodes and their symbiotic bacteria from selected countries or regions of the world. - Biol. Contr. 38: 134-155.

KoppenhöFer A.M., KaYA H.K. \& TAORmino S.P. 1995: Infectivity of entomopathogenic nematodes (Rhabditida: Steinernematidae) at different soil depths and moistures. - J. Invert. Pathol. 65: 193-199.

LACEY L.A. \& GEORGIS R. 2012: Entomopathogenic nematodes for control of insect pests above and below ground with comments on commercial production. - J. Nematol. 44: 218-225.

Laumond C., Mauleon H. \& Kermarrec A. 1979: New data on the host spectrum and the parasitism of the entomophagous nematode, Neoaplectana carpocapsae (biological control). Entomophaga 24: 13-27.

Laznik Z., Tóth T., Lakatos T., Vidrih M. \& Trdan S. 2009: First record of a cold-active entomopathogenic nematode Steinernema kraussei (Steiner) (Rhabditida: Steinernematidae) in Slovenia. - Acta Agric. Sloven. 93: 37-42.

Lewis E.E., Campbell J.F. \& Gaugler R. 1998: A conservation approach to using entomopathogenic nematodes in turf and landscapes. In Barbosa P. (ed.): Conservation Biological Control. Academic Press, New York, pp. 235-254.

LiN Y.J. \& QUEK R.F. 2011: Observations on mass emergence of chironomids (Diptera: Chironomidae) in Bedok, Singapore with notes on human-chironomid interaction. - Nature in Singapore 4: 339-347.

Long S.J., Richardson P.N. \& FENLON J.S. 2000: Influence of temperature on the infectivity of entomopathogenic nematodes (Steinernema and Heterorhabditis spp.) to larvae and pupae of the vine weevil Otiorhynchus sulcatus (Coleoptera: Curculionidae). - Nematology 2: 309-317.

MrÁček Z., BeČVÁR̆ S., Kindlmann P. \& Webster J.M. 1999: Factors influencing the infectivity of a Canadian isolate of Steinernema kraussei (Nematoda: Steinernematidae) at low temperature. - J. Invert. Pathol. 73: 243-247.

NguYen K.B. \& Duncan L.W. 2002: Steinernema diaprepesi sp. (Rhabditida: Steinernematidae), a parasite of the citrus root weevil Diaprepes abbreviatus (L) (Coleoptera: Curculionidae). - J. Nematol. 34: 159-170.

Oliver D.R. 1971: Life history of the Chironomidae. - Annu. Rev. Entomol. 16: 211-230.

Oliver D.R. \& Corbet P.S. 1966: Aquatic Habitats in a High Arctic Locality: The Hazen Camp Study Area, Ellesmere Island, N.W.T. Defence Research Board, Department of National Defence, Ottawa, $115 \mathrm{pp}$.

Pinder L.C.V. 1986: Biology of freshwater Chironomidae. Annu. Rev. Entomol. 31: 1-23.

PoINAR G.O. 1964: A new nematode, Orthomermis oedobranchus gen. n., sp. n. (Mermithidae) parasitizing Smittia larvae (Chironomidae) in England. - Nematologica 10: 501-506.

PoINar G.O. 1979: Nematodes for Biological Control of Insects. CRC Press, Boca Raton, 277 pp.

PoInar G.O. \& Kaul H.N. 1982: Parasitism of the mosquito Culex pipiens by the nematode Heterorhabditis bacteriophora. - J. Invert. Pathol. 39: 382-387.

Prat N. \& RieradeVall M. 1995: Life cycle and production of Chironomidae (Diptera) from Lake Banyoles (NE Spain). Freshw. Biol. 33: 511-524.

Sakai T., Ishizaki T., Sasaki F., Ameshima S., Ohnishi T., Shigemori K., Nakai T., Miyabo S. \& Murakami G. 1993: Adult case of bronchial asthma induced by chironomid midges. Jap. J. Thorac. Dis. 31: 1591-1595.

Shapiro-Ilan D.I. \& Gaugler R. 2002: Production technology for entomopathogenic nematodes and their bacterial symbionts. J. Indust. Microbiol. Biotechnol. 28: 137-146.

STEVENS M.M. 1992: Toxicity of organophosphorus insecticides to fourth-instar larvae of Chironomus tepperi Skuse (Diptera: Chironomidae). - Austral. J. Entomol. 31: 335-337.

Tabaru Y., Moriya K. \& Ali A. 1987: Nuisance midges (Diptera: Chironomidae) and their control in Japan. - J. Am. Mosq. Contr. Assoc. 3: 45-49.

UsHer M.B. \& EDWARDS M. 1984: A dipteran from south of the Antarctic Circle: Belgica antarctica (Chironomidae) with a description of its larva. - Biol. J. Linn. Soc. 23: 19-31.

Welch H.E. \& Bronskill J.F. 1962: Parasitism of mosquito larvae by the nematode DD-136 (Nematodea: Neoaplectanidae). - Can. J. Zool. 40: 1263-1268. 
Willmott D., Hart A., Long S., Edmondson R. \& Richardson P. 2002: Use of a cold-active entomopathogenic nematode Steinernema kraussei to control overwintering larvae of the black vine weevil Otiorhynchus sulcatus (Coleoptera: Curculionidae) in outdoor strawberry plants. - Nematology 4: 925-932.

World Health Organization 2005: Guidelines for Laboratory and Field Testing of Mosquito Larvicides. URL: https://pdfs. semanticscholar.org/fe14/af11cd7696794c2bd11952cd3e06759ca229.pdf
Yang J.S., Nam H.J., Seo M., Han S.K., Choi Y., Nam H.G., LeE S.J. \& KIM S. 2011: OASIS: online application for the survival analysis of lifespan assays performed in aging research. PLOS ONE 6(8): e23525, $11 \mathrm{pp.}$

Received July 18, 2017; revised and accepted November 7, 2017 Published online November 28, 2017

Supplementary file:

Table S1 (http://www.eje.cz/2017/067/S01.xlsx). Statistical analysis of survival of $C$. plumosus exposed to 0, 1000, 2000, 4000, 8000 and 16000 S. feltiae, H. bacteriophora, S. kraussei and $S$. carpocapsae after 5 days exposure. 